\title{
Biochemical characterization of adenosine deaminase (CD26; EC 3.5.4.4) activity in human lymphocyte-rich peripheral blood mononuclear cells
}

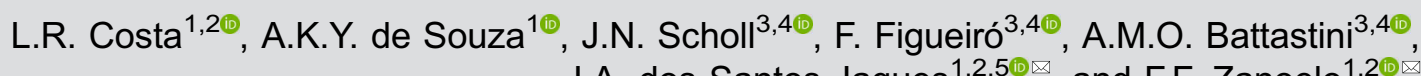 \\ J.A. dos Santos Jaques ${ }^{1,2,5}$, and F.F. Zanoelo ${ }^{1,20}$ \\ ${ }^{1}$ Laboratório de Bioquímica Geral e de Microrganismos, Instituto de Biociências, Universidade Federal de Mato Grosso do Sul, \\ Campo Grande, Campo Grande, MS, Brasil \\ ${ }^{2}$ Programa Multicêntrico de Pós-Graduação em Bioquímica e Biologia Molecular-SBBq, Instituto de Biociências, Universidade \\ Federal de Mato Grosso do Sul, Campo Grande, MS, Brasil \\ ${ }^{3}$ Departamento de Bioquímica, Instituto de Ciências Básicas e da Saúde, Universidade Federal do Rio Grande do Sul, \\ Porto Alegre, RS, Brasil \\ ${ }^{4}$ Programa de Pós-Graduação em Ciências Biológicas, Bioquímica, Instituto de Ciências Básicas e da Saúde, Universidade \\ Federal do Rio Grande do Sul, Porto Alegre, RS, Brasil \\ ${ }^{5}$ Programa de Pós-Graduação em Ciências Farmacêuticas, Faculdade de Farmácia, Alimentos e Nutrição, Universidade Federal \\ de Mato Grosso do Sul, Campo Grande, MS, Brasil
}

\begin{abstract}
The conversion of adenosine to inosine is catalyzed by adenosine deaminase (ADA) (EC 3.5.4.4), which has two isoforms in humans (ADA1 and ADA2) and belongs to the zinc-dependent hydrolase family. ADA modulates lymphocyte function and differentiation, and regulates inflammatory and immune responses. This study investigated ADA activity in lymphocyte-rich peripheral blood mononuclear cells (PBMCs) in the absence of disease. The viability of lymphocyte-rich PBMCs isolated from humans and kept in $0.9 \%$ saline solution at $4-8^{\circ} \mathrm{C}$ was analyzed over $20 \mathrm{~h}$. The incubation time and biochemical properties of the enzyme, such as its Michaelis-Menten constant $\left(\mathrm{K}_{\mathrm{m}}\right)$ and maximum velocity $\left(\mathrm{V}_{\text {max }}\right)$, were characterized through the liberation of ammonia from the adenosine substrate. Additionally, the presence of ADA protein on the lymphocyte surface was determined by flow cytometry using an anti-CD26 monoclonal human antibody, and the PBMCs showed long-term viability after $20 \mathrm{~h}$. The ADA enzymatic activity was linear from 15 to $120 \mathrm{~min}$ of incubation, from 2.5 to $12.5 \mu \mathrm{g}$ of protein, and pH 6.0 to 7.4 . The $\mathrm{K}_{\mathrm{m}}$ and $\mathrm{V}_{\max }$ values were $0.103 \pm 0.051 \mathrm{mM}$ and $0.025 \pm 0.001 \mathrm{nmol} \mathrm{NH} \mathrm{Ng}^{-1} \cdot \mathrm{s}^{-1}$, respectively. Zinc and erythro-9-(2hydroxy-3-nonyl) adenine (EHNA) inhibited enzymatic activity, and substrate preference was given to adenosine over $2^{\prime}$-deoxyadenosine and guanosine. The present study provides the biochemical characterization of ADA in human lymphocyterich PBMCs, and indicates the appropriate conditions for enzyme activity quantification.
\end{abstract}

Key words: Adenosine deaminase; ADA; Lymphocyte-rich PBMCs; Enzymatic assays; Purinergic signaling

\section{Introduction}

Adenosine deaminase (ADA; EC 3.5.4.4), represented in humans by two isoforms, ADA1 and ADA2, catalyzes the conversion of adenosine to inosine (and deoxyadenosine to deoxyinosine) (1-3). Both human ADA isoforms belong to the zinc-dependent hydrolase family and are strongly inhibited by deoxycoformycin and erythro-9(2-hydroxy-3-nonyl) adenine (EHNA). Although ADA is present in all cell types, ADA levels differ widely among tissues. In humans, the highest ADA levels are found in lymphoid tissues (4), and ADA1 influences lymphocyte function. While certain inherited ADA mutations result in severe immunodeficiency, the physiological role of ADA2 is unknown. ADA2 is found in small amounts in the serum and can be produced by monocytes and macrophages (5).

In humans, ADA deficiency manifests primarily as severe lymphopenia and immunodeficiency, and, if untreated, can result in death by six months of age (4). Furthermore, it is associated with failure to thrive and opportunistic infections (4). Enzyme deficiency leads to adenosine (ADA substrate) accumulation, which may induce apoptosis and death in lymphocytes or developmental arrest (6).

Correspondence: F.F. Zanoelo: <ffzanoelo@hotmail.com> | J.A. dos Santos Jaques: <jeandre.jaques@ufms.br> 
The physiological effects of extracellular adenosine are mediated by its interaction with four G-protein-coupled receptors (A1, A2A, A2B, and $A 3)$ (7). These receptors mediate cellular signaling by protecting tissues and organs from damage through a variety of mechanisms that increase oxygen supply and demand, provoke antiinflammatory effects, and stimulate angiogenesis. Studies related to adenosine receptors have shown applications in the treatment of pain, glaucoma, ischemic injuries, asthma, arthritis, cancer, inflammation, and other disorders (8).

Adenosine is considered a neuromodulatory and neuroprotective agent that also functions in other peripheral systems involved in the regulation of blood pressure, immune response, pain, and angiogenesis (3). Under conditions of energy deprivation, adenosine levels increase to influence energy homeostasis in various ways and regulate blood supply and cellular metabolism through maintaining membrane potentials (9).

The quantification of ADA activity has been previously performed in sheep lymphoid cells during antibody production after antigenic stimulation (10), peripheral blood cells of patients with hematological disorders, such as lymphoid leukemia and myeloma (11), serum from patients with different liver disorders (12), serum from patients with acquired immunodeficiency virus (HIV) infection (13), synovial fluid from patients with rheumatoid arthritis (14), serum from patients with tuberculous meningitis (15), serum from patients with chronic lymphoid leukemia (16), and other sources. ADA activity has also been characterized in leukemic cells (17), normal epidermal and carcinoma cells (18), mouse intestines (19), human and chicken livers (20), mollusk (Biomphalaria glabrata) hemolymph (21), and zebrafish brain (22). Although Giusti (23) and Guisti et al. (24) have characterized the enzymatic activity of ADA in human serum, no study has characterized ADA activity in isolated blood lymphocytes in detail, despite that many of the aforementioned studies quantified its activity in these specific cells.

Thus, the aim of this study was to standardize the enzymatic conditions (such as incubation time, protein content, temperature, $\mathrm{pH}$, and ion requirement) and kinetic characteristics of human lymphocyte-rich peripheral blood mononuclear cells (PBMCs), in the absence of disease.

\section{Material and Methods}

\section{Reagents}

Adenosine, 2-deoxyadenosine, guanosine, EDTA, EHNA, Ficoll-Hypaque, Coomassie Blue G, and bovine serum albumin were obtained from Sigma-Aldrich (USA). All other chemicals used in this experiment were of analytical grade of the highest purity.

\section{Participants and ethical aspects}

The Human Research Ethics Committee of the Federal University of Mato Grosso do Sul approved this research (protocol number: CAAE: 89595518.3.0000.0021). All participants provided written informed consent to participate in the study. The selected group included adults over 18 years of age from the Institute of Biosciences at the Federal University of Mato Grosso do Sul (InBio/ UFMS), of both sexes, without reported chronic diseases (for example, high blood pressure and diabetes mellitus), autoimmune diseases, or acute infectious or inflammatory conditions at the time of blood collection. We also excluded smokers, drinkers, and pregnant women. Peripheral blood (approximately $10 \mathrm{~mL}$ per subject) was collected at the Section of Biochemistry (InBio/ UFMS). The participants were randomly selected for the experiments, and four to six participants were required per experiment.

\section{PBMCs isolation}

Human lymphocyte-rich PBMCs were isolated from peripheral blood collected with EDTA (3-4 mL) and separated by Ficoll-Hypaque density gradients, as described by Boyum (25). The collected blood was diluted with an equal volume (1:1) of $0.9 \%$ saline solution, slightly homogenized by inversion, and placed over $3 \mathrm{~mL}$ of Histopaque ${ }^{\mathbb{R}}-1077$ (\#10771, Sigma-Aldrich) in a Falcon tube. The tube was centrifuged at $400 \mathrm{~g}$ for $30 \mathrm{~min}$ at room temperature. Then, we observed the formation of a gradient with an intermediate layer composed of mononuclear cells (mainly lymphocytes and monocytes) between the plasma and Histopaque ${ }^{\circledR}-1077$ layers. The cloud of cells was carefully aspirated and transferred to another tube, which was washed thrice with $0.9 \%$ saline solution and maintained in this solution until use.

\section{Cellular viability}

Cellular viability was determined using the trypan blue dye exclusion method, as described by Strober (26).

\section{Protein concentration determination}

Protein concentration was measured as described by Bradford (27), using the Coomassie blue method and bovine serum albumin as a standard.

\section{Enzymatic assay}

To quantify total ADA activity, the methods described by Guisti et al. (24) and Giusti (23) were used. A standard curve was obtained using $50 \mathrm{mM}$ sodium phosphate buffer ( $\mathrm{pH} 7.0)$, ammonium sulfate, and distilled water. The incubation time and protein concentration varied from 15 to $120 \mathrm{~min}$ and from 1.0 to $20 \mu \mathrm{g}$, respectively. For $\mathrm{pH}$

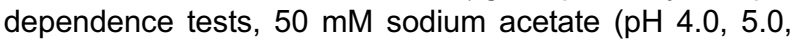
and 6.0), $50 \mathrm{mM}$ sodium phosphate ( $\mathrm{pH} 7.0$ and 7.4), or $50 \mathrm{mM}$ sodium carbonate/bicarbonate $(\mathrm{pH} 8.0$ and 9.0) were used. Adenosine (A9251 - Sigma-Aldrich) was used initially at $20 \mathrm{mM}$. The Michaelis-Menten constant $\left(\mathrm{K}_{\mathrm{m}}\right)$ and maximum velocity $\left(\mathrm{V}_{\max }\right)$ were determined from the Eadie-Hofstee plot, using the adenosine substrate at 
concentrations from 0.1 to $20 \mathrm{mM}$. The incubation temperature was tested at $25,37,45$, and $60^{\circ} \mathrm{C}$. For the specificity assay, adenosine, deoxyadenosine (D7400, Sigma-Aldrich), and guanosine (G6752, Sigma-Aldrich) were used. The influence of zinc $\left(\mathrm{Zn}^{2+}\right)$, calcium $\left(\mathrm{Ca}^{2+}\right)$, magnesium $\left(\mathrm{Mg}^{2+}\right)$, and EDTA, at $5 \mathrm{mM}$ concentrations, was determined. EHNA hydrochloride $(0.1 \mathrm{mM})$ was used as an inhibitor (1261 - TOCRIS Bioscience, USA). The "blank tubes" contained $500 \mu \mathrm{L}$ of reaction medium (20 mM adenosine/50 mM sodium phosphate buffer, $\mathrm{pH}$ 7.0), and the "sample tubes" contained $500 \mu \mathrm{L}$ of reaction medium plus $25 \mu \mathrm{L}$ of the PBMC sample suspended in saline solution. The reaction was stopped with the addition of $1500 \mu \mathrm{L}$ of a phenol/nitroprusside solution (106 mM phenol and $0.17 \mathrm{mM}$ nitroprusside) and $1500 \mu \mathrm{L}$ of alkaline hypochlorite. After that, $25 \mu \mathrm{L}$ of the PBMC sample was added to the "blank tubes," and then, the tubes were incubated again for $30 \mathrm{~min}$ at $37^{\circ} \mathrm{C}$ to measure the presence of ammonium $\left(\mathrm{NH}_{4}{ }^{+}\right)$. The enzymatic activity was determined spectrophotometrically using a Genesys 10S UV-VIS spectrophotometer (Thermo Scientific, USA) at $620 \mathrm{~nm}$ and reported as nmol of $\mathrm{NH}_{3} \cdot \mathrm{mg}^{-1} \cdot \mathrm{s}^{-1}$.

\section{Flow cytometry analysis}

Three lymphocyte-rich PBMC samples were separated, washed with blocking buffer, and stained with mouse anti-human CD26-FITC conjugated antibody or an isotype control. Incubation occurred in the dark for 30 min at room temperature. After incubation, cells were washed twice with phosphate-buffered saline $(\mathrm{pH} 7.0)$. Then, the cells were suspended in phosphate-buffered saline $(\mathrm{pH} 7.0)$ and immediately analyzed using a BD Accuri C6 flow cytometer and C6 software (BD Bioscience, USA), gating on lymphocytes in the side scatter (SSC) vs forward scatter (FSC) dot plot.

\section{Statistical analysis}

Data were analyzed using Student's t-test or one-way analysis of variance (ANOVA) followed by the Tukey's post hoc test. Results with $\mathrm{P} \leqslant 0.05$ were considered statistically significant. The Pearson correlation was used for the linearity analysis of time and protein concentration. Kinetic parameters were calculated using GraphPad Prism 6.0 software (GraphPad Software, USA)

\section{Results}

The results demonstrated that human lymphocyte-rich PBMCs maintained a high viability (Figure 1), even $20 \mathrm{~h}$ after separation, which allowed the cells to be used in the subsequent assays, without the need for immediate enzymatic quantification after isolation. For the first ADA activity assays, $20 \mathrm{mM}$ adenosine substrate was used, as recommended by Guisti et al. (24), until the ideal conditions were determined. The adenosine deamination

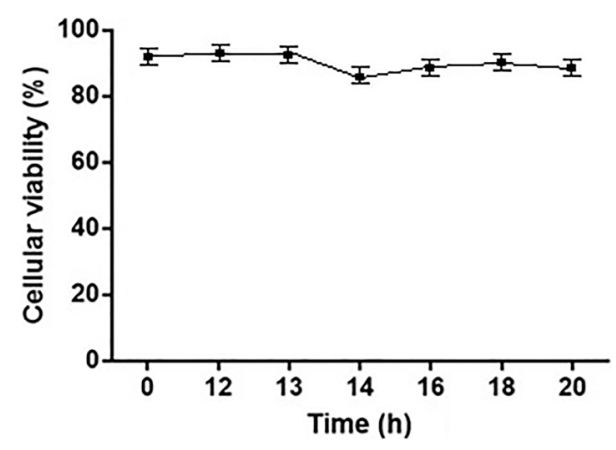

Figure 1. Cellular viability of human lymphocyte-rich peripheral blood mononuclear cells, determined using the Trypan Blue dye exclusion method, over a $20-h$ period $(n=3)$. The data are reported as means \pm SE.

of human lymphocyte-rich PBMCs isolated from peripheral blood was evaluated as a function of time, protein concentration, and kinetic constant, in order to determine the correct assay conditions. The enzyme activity was linear from 15 to $120 \mathrm{~min}$ (Figure 2A). Thus, an incubation time of 120 min was chosen for the posterior experiments. The deamination promoted by ADA activity remained linear in the range of 2.5 to $12.5 \mu \mathrm{g}$ of protein (Figure $2 \mathrm{~B}$ ). Thus, for the following experiments, the protein content of the samples was set to values close to $12.5 \mu \mathrm{g}$ of protein.

To calculate the kinetic parameters, we tested ADA activity at adenosine concentrations ranging from 0.1 to $20 \mathrm{mM}$. The apparent $\mathrm{K}_{\mathrm{m}}$ and $\mathrm{V}_{\max }$ were estimated with Eadie-Hofstee plots to be $0.103 \pm 0.051 \mathrm{mM}$ and 0.025 $\pm 0.001 \mathrm{nmol} \mathrm{NH} \mathrm{mg}_{3} \cdot \mathrm{mg}^{-1}$, respectively (Figure $2 \mathrm{C}$ ). For the following tests, adenosine was used at a concentration of $10 \mathrm{mM}$, enough to achieve $V_{\text {max }}$.

To determine the influence of $\mathrm{pH}$ on ADA activity, the enzyme assay was carried out in the $\mathrm{pH}$ range of 4.0 to 9.0. The relative enzymatic activity levels plateaued and remained higher in the $\mathrm{pH}$ range from 6.0 to 7.4 (Figure 3A). Therefore, for the following assays, sodium acetate buffer $(50 \mathrm{mM}) \mathrm{pH} 6.0$ was chosen. The effect of temperature at $25,37,45$, and $60^{\circ} \mathrm{C}$ was also evaluated (Figure $3 \mathrm{~B}$ ). The relative enzymatic activity increased at $60^{\circ} \mathrm{C}$; however, a temperature of $37^{\circ} \mathrm{C}$ was chosen in the subsequent experiments, as this is the most stable temperature for biological systems involving human cells.

The effects of different divalent metal ions $(5.0 \mathrm{mM}$ $\mathrm{CaCl}_{2}, \mathrm{MgCl}_{2}$, or $\mathrm{ZnCl}_{2}$ ) and $5.0 \mathrm{mM}$ EDTA on ADA activity were determined. $\mathrm{ZnCl}_{2}$ inhibited the enzyme, while the other metal ions did not affect the enzymatic activity at a concentration of $5.0 \mathrm{mM}$. EDTA (when incubated with $\mathrm{ZnCl}_{2}$ ) prevented the inhibition of the enzyme by zinc (Figure 4).

The substrate specificity of the lymphocyte-rich PBMCs ADA was evaluated (Table 1). The ADA showed the highest preference for adenosine $(100 \%)$, followed by 2 '-deoxyadenosine (57\%) and guanosine (2.3\%). Several 

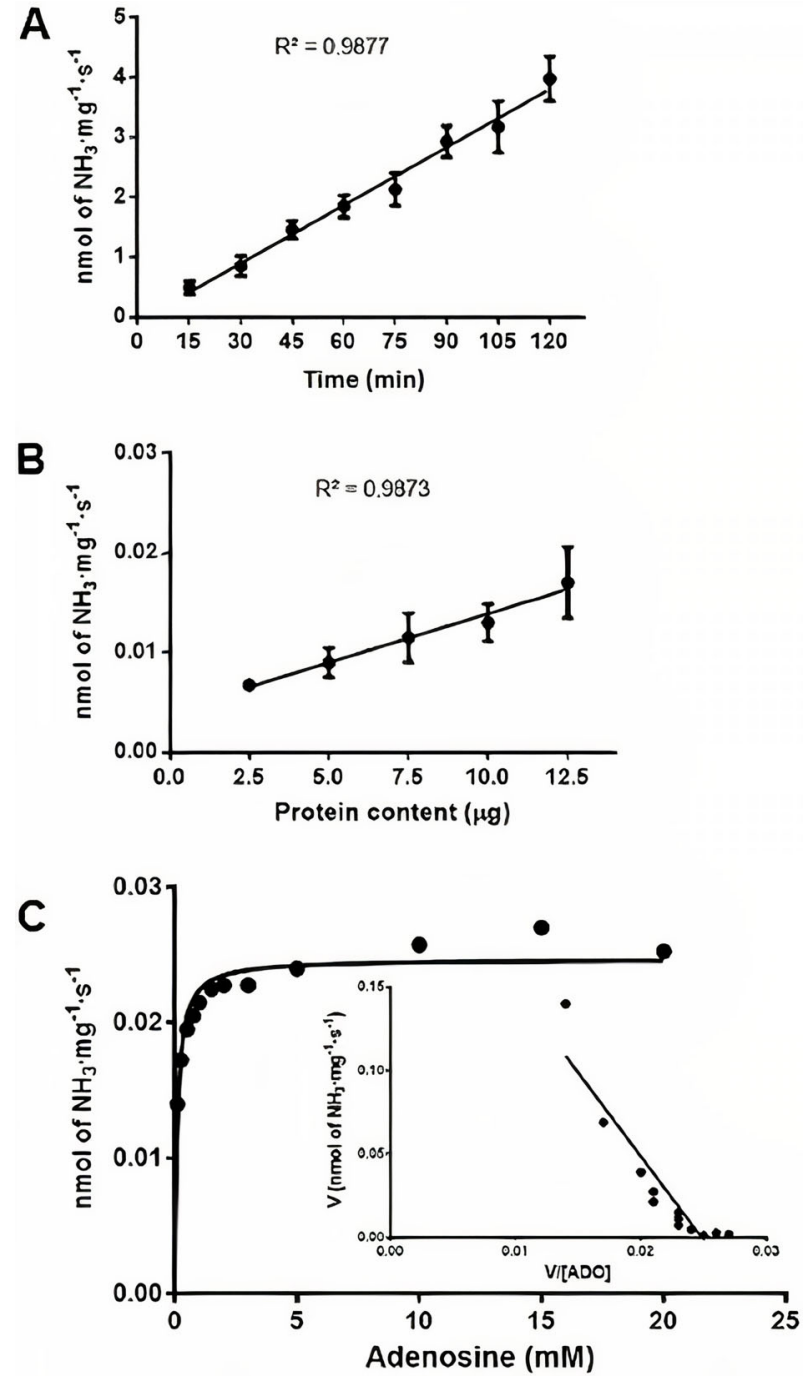

Figure 2. Enzymatic parameters of adenosine deaminase (ADA) activity in human lymphocyte-rich peripheral blood mononuclear cells. A, Effect of time on ADA activity $(n=4)$. B, Effect of protein content on ADA activity $(n=4)$. C, Substrate effect with MichaelisMenten equation for determination of $\mathrm{K}_{\mathrm{m}}$ and $\mathrm{V}_{\max }$ and EadieHofstee plot $(n=4)$. The data are reported as means \pm SE.

studies have demonstrated that EHNA is a potent inhibitor of ADA1 activity $(1,20)$. Thus, we measured adenosine deamination in human lymphocyte-rich PBMCs in the presence and absence of EHNA. The ADA activity was strongly inhibited by EHNA at a concentration of $0.1 \mathrm{mM}$ (Table 2 ), showing only $1.7 \%$ activity after incubation with the inhibitor.

Since the association of ADA with CD26 to form a dimer has been previously described in the literature (1), PBMCs were labeled with an anti-CD26 antibody and analyzed by flow cytometry. Thus, it was possible to indirectly confirm the presence of ADA in mononuclear cells.

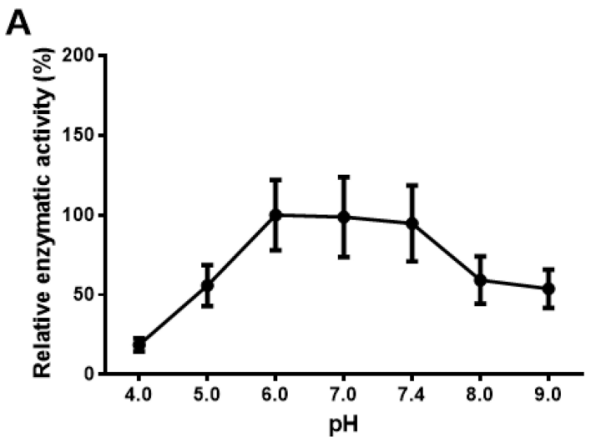

B

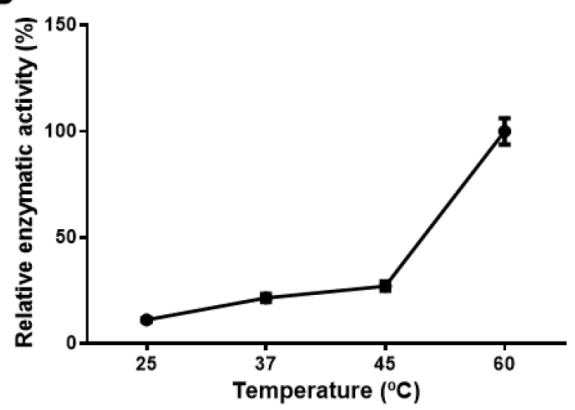

Figure 3. Effect of $\mathrm{pH}(\mathbf{A})$ and temperature (B) on adenosine deaminase (ADA) activity in human lymphocyte-rich peripheral blood mononuclear cells. After incubation, ADA activity was assayed under standard conditions. The data are reported as means \pm SE

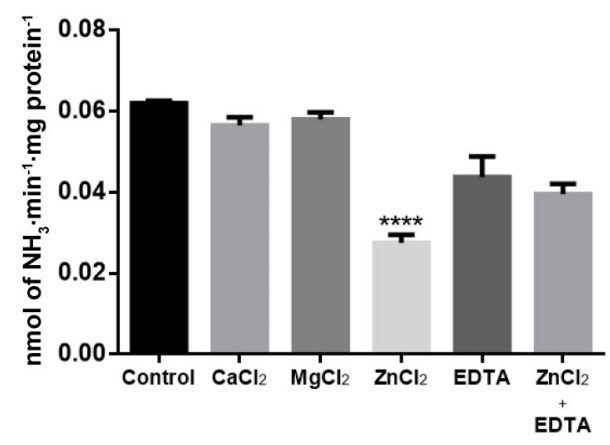

Figure 4. Effect of ions on adenosine deaminase (ADA) activity in human lymphocyte-rich peripheral blood mononuclear cells $(n=4)$. The final concentration of $\mathrm{CaCl}_{2}, \mathrm{MgCl}_{2}, \mathrm{ZnCl}_{2}$, and EDTA was $5.0 \mathrm{mM}$. Control: without ions or EDTA. The data are reported as means \pm SE for $n=4$. ${ }^{* * * *} \mathrm{P}<0.001$ compared to control group (ANOVA followed by Tukey test).

\section{Discussion}

In the present study, the biochemical properties of ADA activity in human lymphocyte-rich PBMCs were evaluated. In humans, ADA is represented by two isoforms, ADA1 and ADA2, which belong to the zincdependent hydrolase family. The presence of these enzymes may regulate adenosine/inosine levels in human 
Table 1. Adenosine deaminase (ADA) substrate specificity in human lymphocyte-rich peripheral blood mononuclear cells (10 mM; n=4).

\begin{tabular}{lcc}
\hline Substrate & ADA activity & Relative activity (\%) \\
\hline Adenosine & $0.06354 \pm 0.00504$ & $100 \pm 7.9$ \\
2'-deoxyadenosine $^{\prime}$ & $0.03636 \pm 0.00299^{* *}$ & $57.2 \pm 4.7$ \\
Guanosine & $0.00148 \pm 0.00001^{* *}$ & $2.3 \pm 0.01$ \\
\hline
\end{tabular}

Enzymatic activity is reported in $\mathrm{nmol}$ of $\mathrm{NH}_{3} \cdot \mathrm{mg}^{-1} \cdot \mathrm{s}^{-1}$. The data are reported as means $\pm \mathrm{SE}$. ${ }^{* *} \mathrm{P}<0.01$ compared to adenosine (one-way ANOVA, followed by Tukey post-test).

Table 2. Adenosine deaminase (ADA) inhibition in human lymphocyte-rich peripheral blood mononuclear cells by erythro9-(2-hydroxy-3-nonyl) adenine (EHNA) $(n=4)$.

\begin{tabular}{lcc}
\hline Group & ADA activity & Relative activity (\%) \\
\hline Control & $0.0583 \pm 0.0046$ & $100 \pm 7.9$ \\
EHNA $(0.1 \mathrm{mM})$ & $0.0010 \pm 0.0001^{* * *}$ & $1.7 \pm 0.1$ \\
\hline
\end{tabular}

Enzymatic activity is reported in $\mathrm{nmol}$ of $\mathrm{NH}_{3} \cdot \mathrm{mg}^{-1} \cdot \mathrm{s}^{-1}$. The data are reported as means $\pm \mathrm{SE}$. ${ }^{* \star *} \mathrm{P}<0.0001$ compared to control (Student's $t$-test).

lymphocyte-rich PBMCs to modulate lymphocyte function and differentiation and inflammatory and immune responses $(1,3,9)$.

To quantify the activity of enzymes located on the outer surface of the cell membrane, it is necessary to ensure cell integrity and viability for accurate enzymatic quantification, especially when there are intracellular enzymes that might mimic the activity of interest. ADA is located on the plasma membrane in various cells, such as lymphocytes, with its catalytic site facing the extracellular matrix $(1,23)$. One of the most commonly used peripheral lymphocyte isolation methods is density gradient separation $(25,28)$. The results demonstrated that human lymphocyte-rich PBMCs maintained a high viability, even $20 \mathrm{~h}$ after separation.

The enzyme activity was linear from 15 to $120 \mathrm{~min}$, and thus, an incubation time of 120 min was chosen, and the enzyme activity remained linear in the range of 2.5 to $12.5 \mu \mathrm{g}$ of protein. Rosemberg et al. (22) characterized ADA in the zebrafish brain and obtained linearity in enzymatic activity up to $105 \mathrm{~min}$ for the soluble enzyme fraction and 180 min for the membrane fraction. The same authors showed that the protein content was linear from 5.0 to $20 \mu \mathrm{g}$, similar to what was identified in the present study.

The substrate curve demonstrated that the apparent $\mathrm{K}_{\mathrm{m}}$ and $\mathrm{V}_{\max }$ for adenosine were $0.103 \pm 0.051 \mathrm{mM}$ and $0.025 \pm 0.001 \mathrm{nmol}$ of $\mathrm{NH}_{3} \cdot \mathrm{mg}^{-1} \cdot \mathrm{s}^{-1}$, respectively. The apparent $\mathrm{K}_{\mathrm{m}}$ of ADA with adenosine substrate has been reported in other tissues and cells, usually presenting lower values; however, in the same order, similar to our result $(17-22,29)$. The physiological concentration of adenosine in human plasma is approximately $0.1 \mu \mathrm{M}$ (30), which suggests that ADA activity is very low under basal conditions (31).

The influence of $\mathrm{pH}$ on ADA activity was verified, and the results demonstrated that the optimal $\mathrm{pH}$ levels hit a plateau and remained high in the $\mathrm{pH}$ range from 6.0 to 7.4. Koizumi et al. (18) characterized ADA in normal human epidermal and carcinoma cells, and found that $\mathrm{pH} 7.0$ was optimal. Singh and Sharma (19) characterized this enzyme in the mouse intestine, and found $\mathrm{pH}$ stability between 6.5 and 9.0. Additionally, Lindley and Pisoni (29) identified the optimal pH between 7.0 and 8.0 in human fibroblast lysosomes. Thus, the results obtained in this study are in agreement with the literature. The effect of temperature was also evaluated, and the relative enzymatic activity reached its maximum at $60^{\circ} \mathrm{C}$. The increase in ADA activity at high temperatures has been previously described, but $37^{\circ} \mathrm{C}$ is commonly used in enzyme assays because of the risk of protein denaturation at higher temperatures (22). Vale et al. (21) observed higher ADA activity at $37^{\circ} \mathrm{C}$ and a loss of activity when the samples were incubated at $50^{\circ} \mathrm{C}$. However, Koizumi et al. (18) reported that in normal human epidermal and carcinoma cells, a larger ADA isoform was stable up to $65^{\circ} \mathrm{C}$.

In order to verify whether adenosine deamination in human lymphocyte-rich PBMCs is altered in the presence of divalent cations, ADA was incubated in the presence and absence of $5 \mathrm{mM} \mathrm{Ca}^{2+}, \mathrm{Mg}^{2+}, \mathrm{Zn}^{2+}$, and EDTA. The

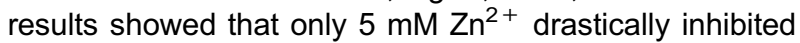
the enzyme, and EDTA (when incubated with $\mathrm{ZnCl}_{2}$ ) prevented the effect of zinc on the enzyme. Zinc plays an important role in adenosine deamination because it is located at the active site of ADA. It has also been shown that zinc (and other divalent cations) can interact with amino acid residues and cause substrate-competitive inhibition of enzymatic activity. It has been suggested that zinc may interact with amino acid residues located at or near the active site and form a metal bond that is similar to those found in "zinc finger" structures. If so, this would occupy a portion of the active site and interfere with substrate binding (32).

In relation to the substrate specificity, ADA showed a preference for adenine over 2'-deoxyadenosin and guanine nucleosides, and the guanine nucleosides were deaminated at considerably lower rates than the adenine nucleosides (21). Iwaki-Egawa and Watanabe (20) characterized purified human and chicken liver ADAs, and their results showed that ADA has a preference for adenosine over deoxyadenosine, in agreement with the results obtained with human lymphocyte-rich PBMCs in the present study.

Since EHNA is a specific ADA1 inhibitor (1) and showed significant ADA inhibition in human lymphocytes, we can assume that ADA1 is the predominant isoform 
in these cells. This inhibitor has been used at the same concentration in other studies and was confirmed to have an effect on ADA1 alone, as described by IwakiEgawa and Watanabe (20). The human lymphocyte-rich PBMCs were labeled with anti-CD26 antibody or isotype control and analyzed by flow cytometry. Thus, it was possible to indirectly confirm the presence of ADA in PBMC.

The quantification of ADA activity in human lymphocytes has been previously performed $(1,10,16)$, but no prior studies have performed detailed biochemical and kinetic characterizations. Thus, the present study provided the biochemical characterization of ADA in lymphocyterich PBMCs and identified the appropriate conditions for enzyme activity quantification. The described kinetic characteristics and conditions will improve the quantification of ADA activity in human lymphocytes in future studies and improve our understanding of the role of the purinergic system in these cells.

\section{References}

1. Zavialov AV, Engström A. Human ADA2 belongs to a new family of growth factors with adenosine deaminase activity. Biochem J 2005; 391: 51-57, doi: 10.1042/BJ20050683.

2. Kukulski F, Lévesque SA, Sévigny J. Impact of ectoenzymes on $\mathrm{P} 2$ and $\mathrm{P} 1$ receptor signaling. In: Jacobson KA, Linden J (Editors), Pharmacology of purine and pyrimidine receptors. San Diego: Elsevier Inc.; 2011. p 263-288.

3. Burnstock G, Verkhratsky A. Purinergic signalling and the nervous system [eBook]. Berlin Heidelberg: Springer-Verlag. 2012, doi: 10.1007/978-3-642-28863-0; ISBN: 978-3-64228863-0.

4. Aldrich MB, Blackburn MR, Kellems RE. The importance of adenosine deaminase for lymphocyte development and function. Biochem Biophys Res Commun 2000; 272: 311315, doi: $10.1006 /$ bbrc.2000.2773.

5. Zavialov AV, Gracia E, Glaichenhaus N, Franco R, Zavialov AV, Lauvau G. Human adenosine deaminase 2 induces differentiation of monocytes into macrophages and stimulates proliferation of $\mathrm{T}$ helper cells and macrophages. $J$ Leukoc Biol 2010; 88: 279-290, doi: 10.1189/jlb.1109764.

6. Hershfield MS, Mitchell BS. Immunodeficiency diseases caused by adenosine deaminase deficiency and purine nucleoside phosphorylase deficiency. In: Scriver CM, Beaudet AL, Sly W, Valle D (Editors), Metabolic basis of inherited disease. 7th edn. New York: McGraw-Hill; 1995. p 1725-1768, doi: 10.1036/ommbid.137.

7. Lane JR, Jaakola V, ljzerman AP. The structure of the adenosine receptors: implications for drug discovery. In: Jacobson KA, Linden J (Editors), Pharmacology of purine and pyrimidine receptors. San Diego: Elsevier Inc.; 2011. p 1-34.

8. Gessi S, Merighi S, Varani K, Borea PA. Adenosine receptors in health and disease. In: Jacobson KA, Linden $\mathrm{J}$ (Editors), Pharmacology of purine and pyrimidine receptors. San Diego: Elsevier Inc.; 2011. p 41-65.
Finally, we highlight that the method employed in this study for cellular isolation yields a population of PBMCs rich in lymphocytes, but with the presence of non-lymphoid cells mostly composed by monocytes. Depending on the study design, this limitation should be considered.

\section{Acknowledgments}

This study was financed in part by the Coordenação de Aperfeiçoamento de Pessoal de Nível Superior - Brasil (CAPES, Finance Code 001). J.N. Scholl received a fellowship from Conselho Nacional de Desenvolvimento Científico e Tecnológico (CNPq). A.M.O. Battastini is a recipient of a research fellowship ( $P Q$ ) from Conselho Nacional de Desenvolvimento Científico e Tecnológico (CNPq, project number 302879/2017-0). This study was supported by the Universidade Federal de Mato Grosso do Sul and Programa Multicêntrico de Pós-Graduação em Bioquímica e Biologia Molecular (SBBq).

9. Burnstock G. Purinergic signalling. Br J Pharmacol 2006; 147: S172-S181, doi: 10.1038/sj.bjp.0706429.

10. Hall JG. Adenosine deaminase activity in lymphoid cells during antibody production. Aust J Exp Biol Med Sci 1963; 41: 93-97, doi: 10.1038/icb.1963.8.

11. Meier J, Coleman MS, Hutton JJ. Adenosine deaminase activity in peripheral blood cells of patients with haematological malignancies. $\mathrm{Br} J$ Cancer 1976; 33: 312-319, doi: 10.1038/bjc.1976.45

12. Sanchez RA, Pérez H, Sánchez R, Sánchez FD, González JA, Péres-Sandoval D, et al. Enzymatic activity of serum adenosine deaminase in different liver disorders. An Med Interna 1989; 6: 300-304.

13. Gakis C, Calia G, Naitana A, Pirino D, Serru G. Serum adenosine deaminase activity in HIV positive subjects. A hypothesis on the significance of ADA2. Panminerva Med 1989; 31: 107-113.

14. Nakamachi $Y$, Koshiba M, Nakazawa T, Hatachi S, Saura $R$, Kurosaka $M$, et al. Specific increase in enzymatic activity of adenosine deaminase 1 in rheumatoid synovial fibroblasts. Arthritis Rheum 2003; 48: 668-674, doi: 10.1002/ art.10956.

15. Cho BH, Kim BC, Yoon GJ, Choj SM, Chang J, Lee SH, et al. Adenosine deaminase activity in cerebrospinal fluid and serum for the diagnosis of tuberculous meningitis. Clin Neuro Neurosurg 2013; 115: 1831-1836, doi: 10.1016/ j.clineuro.2013.05.017.

16. Ghaderi B, Amini S, Maroofi F, Jalali C, Javanmardi M, Roshani $D$, et al. Adenosine deaminase activity in chronic lymphocytic leukemia and healthy subjects. Iran J Cancer Prev 2016; 9: e5069, doi: 10.17795/ijcp-5069.

17. Morisaki T, Fujii $H$, Miwa S. Adenosine deaminase (ADA) in leukemia: clinical value of plasma ADA activity and characterization of leukemic cell ADA. American J Hematol 1985; 19: 37-45, doi: 10.1002/ajh.2830190106. 
18. Koizumi H, Ilzuka H, Aoyagi T, Miura Y. Characterization of adenosine deaminase from normal human epidermis and squamous cell carcinoma of the skin. $J$ Investigative Dermatol 1985; 84: 199-202, doi: 10.1111/1523-1747. ep12264833.

19. Singh L, Sharma R. Purification and characterization of intestinal adenosine deaminase from mice. Mol Cel Biochem 2000; 204: 127-134, doi: 10.1023/A:1007087905192.

20. Iwaki-Egawa S, Watanabe Y. Characterization and purification of adenosine deaminase 1 from human and chicken liver. Comp Bioch Physiol B Biochem Mol Biol 2002; 133: 173-182, doi: 10.1016/S1096-4959(02)00122-7.

21. Vale MR, Pereira RV, Almeida SM, Almeida YM, Nunes SFLC. Characterization of adenosine deaminase (ADA) in hemolymph of Biomphalaria glabrata. Braz $J$ Biol 2005; 65: 371-376, doi: 10.1590/S1519-6984200500 0200022.

22. Rosemberg DB, Rico EP, Senger MR, Dias RD, Bogo MR, Bonan CD, et al. Kinetic characterization of adenosine deaminase activity in zebrafish (Danio rerio) brain. Comp Biochem Physiol B Biochem Mol Biol 2008; 151: 96-101, doi: 10.1016/j.cbpb.2008.06.001.

23. Giusti G. Adenosine deaminase. In: Bergmeyer HU (Editor). Methods Enz Anal. 2nd Edition. New York: Academic Press; 1974. p 1092-1099.

24. Giusti G, Gakis C. Temperature conversion factors, activation energy, relative substrate specificity and optimum $\mathrm{pH}$ of adenosine deaminase from human serum and tissues. Enzyme 1971; 12: 417-425, doi: 10.1159/000459567.
25. Boyum A. Isolation of mononuclear cells and granulocytes from human blood. Isolation of mononuclear cells by one centrifugation, and of granulocytes by combining centrifugation and sedimentation at $1 \mathrm{~g}$. Scand J Clin Lab Invest Supp/ 1968; 97: 77-89.

26. Strober W. Trypan blue exclusion test of cell viability. Curr Protoc Immunol 2001; Appendix 3: Appendix 3B, doi: 10.1002/0471142735.ima03bs21.

27. Bradford MM. A rapid and sensitive method for the quantitation of microgram quantities of protein utilizing the principle of protein-dye binding. Anal Biochem 1976; 72: 248-254, doi: 10.1016/0003-2697(76)90527-3.

28. Brosseron F, Marcus K, May C. Isolating peripheral lymphocytes by density gradient centrifugation and magnetic cell sorting. Methods Mol Biol 2015; 1295: 33-42, doi: 10.1007/978-1-4939-2550-6.

29. Lindley ER, Pisoni RL. Demonstration of adenosine deaminase activity in human fibroblast lysosomes. Biochem $J$ 1993; 290: 457-462, doi: 10.1042/bj2900457.

30. German DC, Kredich NM. A radioenzymatic assay for plasma adenosine. Anal Biochem 1984; 42: 536-541, doi: 10.1016/0003-2697(84)90503-7.

31. Koupenova M, Kehrel BE, Heather A. Corkrey HÁ, Freedman JE. Thrombosis and platelets: an update. Eur Heart J 2017; 38: 785-791, doi: 10.1093/eurheartj/ehw550.

32. Cooper FB, Sideraki V, Wilson DK, Dominguez DY, Clark SW, Quiocho FA, et al. The role of divalent cations in structure and function of murine adenosine deaminase. Protein Sci 1997; 6: 1031-1037, doi: 10.1002/pro.5560060509. 